\title{
Geomorphology of Lake Ladoga basin
}

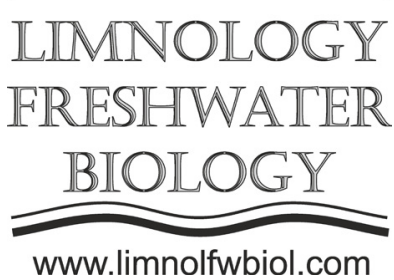

\author{
Aksenov A.O. ${ }^{1,2 *}$, Rybalko A.E. ${ }^{1,3}$, Naumenko M.A. ${ }^{4}$ \\ ${ }^{1}$ St Petersburg University, Universitetskaya emb., 7/9, Saint-Petersburg, 199034, Russia \\ ${ }^{2}$ Arctic and Antarctic Reseasrch Institute, Beringa str., 38, Saint-Petersburg, 199397, Russia \\ ${ }^{3}$ FSBI "VNIIOkeangeologia", Angliyskiy av., 1, Saint-Petersburg, 190121, Russia \\ ${ }^{4}$ Institute of Lymnology of Russian Academy of Science, Sevastianova str., 9, Saint-Petersburg, 196105, Russia
}

\begin{abstract}
This work presents results of geomorphological analysis of the Ladoga lake's bottom, based on geophysical and bathymetrical data. The final approach of this investigation is geomorphological scheme with scale 1:1 000000 . The digital elevation model of M.A. Naumenko with spatial distribution 0,5 ' X 0,5 ' was used as a bathymetrical base. Geophysical part of data are seismoacoustic profiles covering the whole basin with total length in $1304 \mathrm{~km}$. They were received in expeditions of St. Petersburg University, Marine Research Center at Moscow State University and Northern Water Problems Institute KarRC RAS. Geomorphological analysis allows us to mark 6 genetic types. Two types was related to denudative types (denudative structural and erosive subaqual) and four - to accumulative types (glacial, fluvioglacial, glacial lacustrine and lacustrine). Four main factors in to form of bottom structure Lake Ladoga during the Late Glacial-Holocene were identified. A neotectonical factor was mostly significant. In addition, there were exogenous factors to form sediment cover of the basin: glacial activity, glacial lacustrine accumulation of varved clays and modern processes of lacustrine accumulation and abrasion of older sediments.
\end{abstract}

Keywords: Lake Ladoga, bottom geomorphology, Holocene, seismoacoustic profiling, digital elevation model

\section{Introduction}

Lake Ladoga is the biggest fresh-water body in Europe (area $17765 \mathrm{~km}^{2}$, volume $848 \mathrm{~km}^{3}$, mean depth $48,3 \mathrm{~m}$ ). It is an important object of social and economic structure of Saint-Petersburg and northwestern part of Russia. From the geological point of view, the main feature of the lake bottom is its location on the boundary of two geological structures: the Russian plate and the Baltic crystalline shield (Subetto et al., 1998), which determine differences of the depth distribution in the lake. Many investigations of the lake have been already made including researches on fundamental geology (Amantov \& Spiridonov, 1989; Amantov, 2014), quaternary geology (Subetto et al., 1998; Subetto, 2009), bottom sediments (Semenovich, 1966), however, publications related with bottom geomorphology of the lake are still rare. The main purpose of this study is to create a geomorphological scheme of 1:1 000000 scale (Fig. 1,2) and analysis of Lake Ladoga bottom geomorphological features.

\section{Materials and methods}

Combination of geophysical and bathymetric data was used for complex research. Geophysical material consists of seismoacoustic profiles which were made in expeditions of St. Petersburg University (SPbU), Marine Research Center at Moscow State University (MRC at MSU) and Northern Water Problems Institute KarRC RAS (NWPI KarRC Ras) in 2014 (northern part of the lake) and 2015 (southern one). Overall, profiles' length is about $1304 \mathrm{~km}$. They were executed with seismoacoustic devices "Boomer" and "Sparker" on research vessel "Ecolog" of NWPI KarRC RAS. The method of multichannel low frequency seismic profiling was used.

Bathymetrical part includes digital elevation model (DEM) of Ladoga lake's bottom developed in Lymnological Institute RAS by Naumenko M.A. (Naumenko, 2020) It was made with extrapolation of depth values from bathymetrical maps of 1:100 000 scale. There have been already made some investigations based on this DEM (Naumenko, 2013; Anokhin et al., 2016). In this investigation grid with step 30 ', processed in Surfer 13 Golden Software, was used.

Scheme building was done in ArcMap 10.6.1 ESRI ArcGIS. DEM and transects of seismoacoustic profiles were loaded and correlated there. Authors used an analytical method of the geomorphological mapping. It based on mapping genetically homogenous

*Corresponding author.

E-mail address: aksenov2801@gmail.com (A.O. Aksenov) 


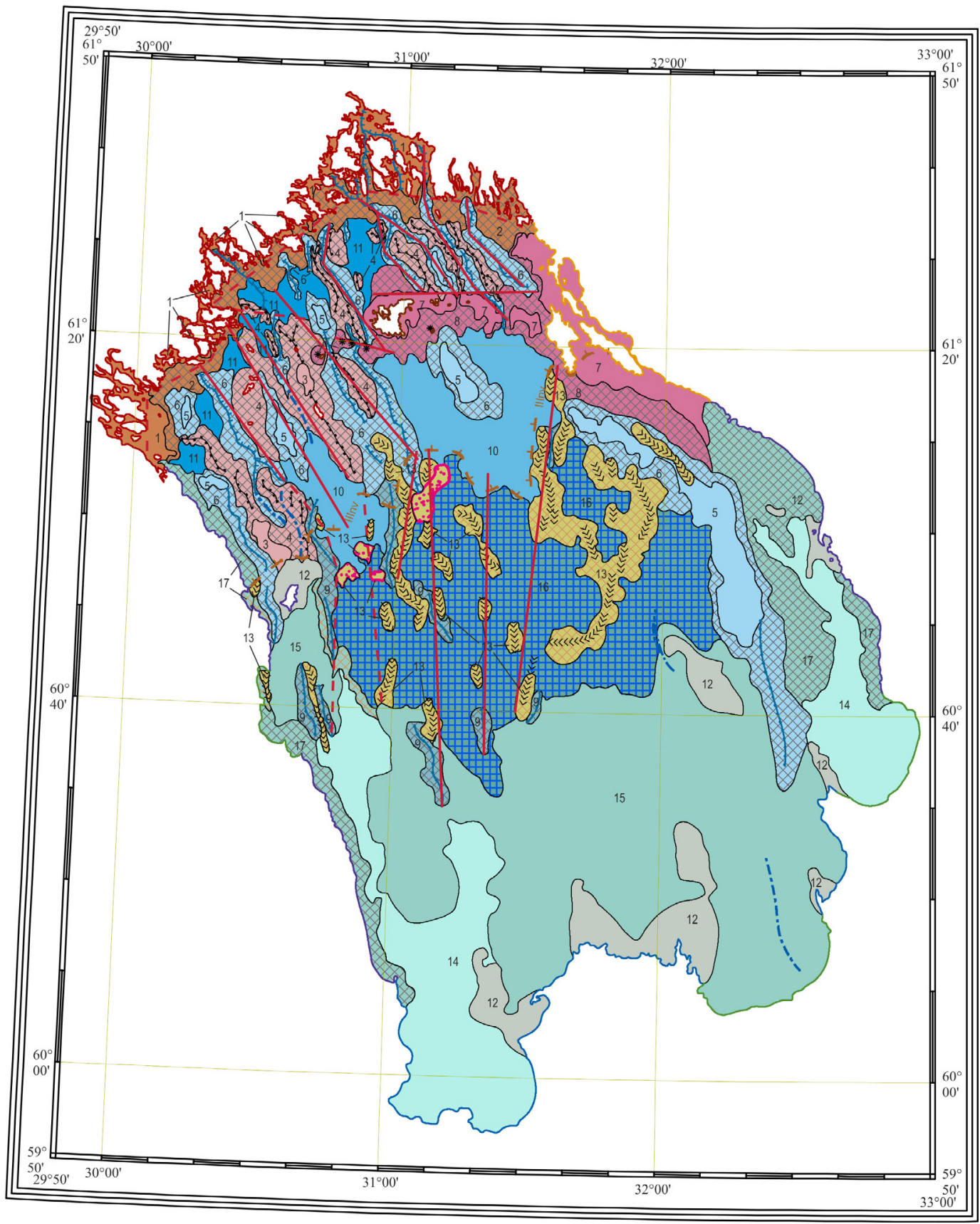

Fig.1. Geomorphological scheme of lake Ladoga bottom (off-scale)

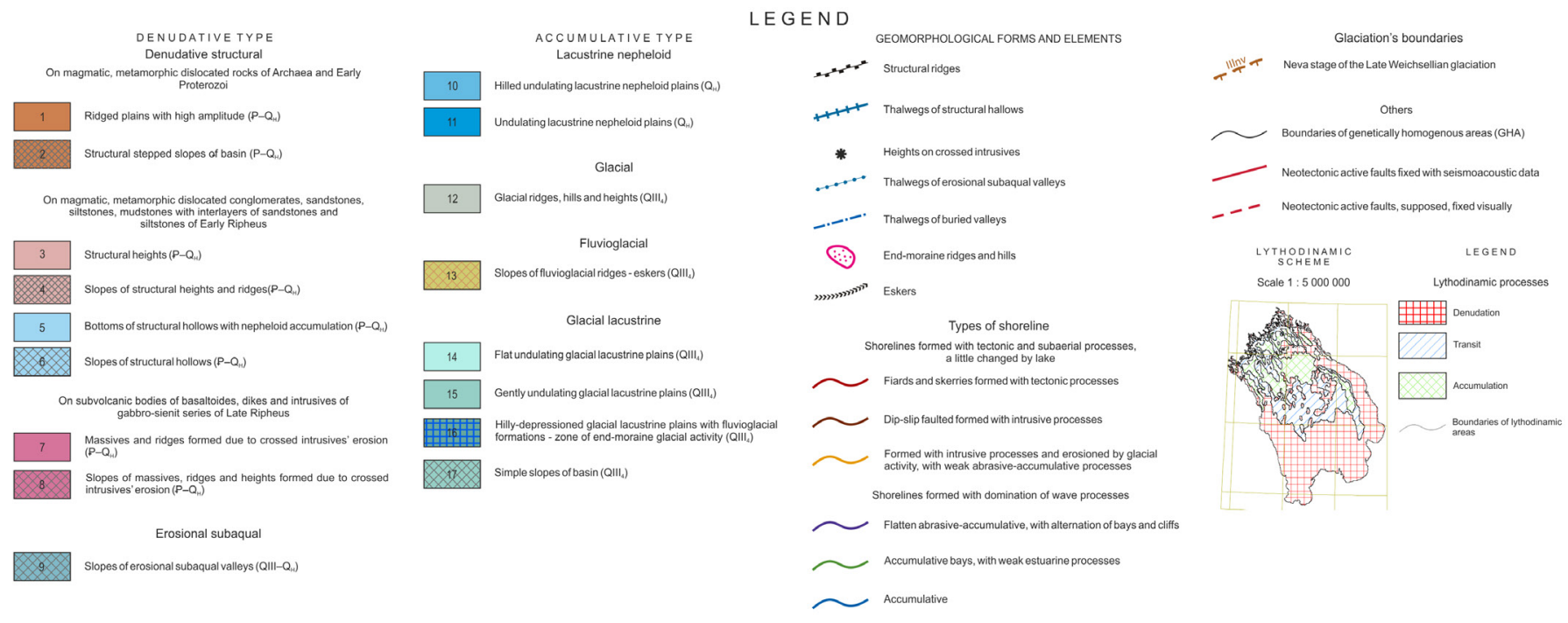

Fig.2. Legend to the geomorphological scheme 
areas (GHA), which are divided by their morphology, genesis and age, and their separation as slope and subhorizontal areas. GHA's morphology was extracted from DEM data, genesis and age - from seismoacoustic data. GHA were mapped as area elements, those that had been out of scale - as linear and point elements. The scheme is designed according to rules and demands of VSEGEI.

\section{Results}

Six geomorphological types and 17 kinds of GHA were identified. They depend on geological structure, history of development and sediments' composition. First one is a denudative structural. It occupies the most part of northern lake's half. Combination of heights, parallel ridges and hollows compose this type. They are determined and formed by structure of Baltic Crystalline Shield. Morphology is characterized by high amplitudes and elongated forms. Hollows, despite of the fact that they belong to denudative type, are filled with quaternary sediments with thickness up to $100 \mathrm{~m}$. Thickness of sediments at raised areas is less due to denudation and they consist of glacial till and glacial lacustrine varved clays. Special case is the heights of intrusive Early Rifeus rocks. These are forms based on Valaamo sill and dikes of Valaamsko-Staroladozhskaya and Vidlitsko-Svirskaya intrusive zones (Amantov, 2014). Second denudative type is erosional subaqual, which is presented by opened and buried valleys. Opened ones are located in southern and middle part of the lake where accumulation processes are weak due to low depth. They are filled with fluvial and fluvioglacial sediments. In buried valleys Holocene lacustrine sediments accumulate.

Accumulative types represent glacial, fluvioglacial, glacial lacustrine and lacustrine processes. Glacial ridges, hills and heights are located in southern shallow-water part of the basin. Most part of their bodies consists of glacial sediments with thickness about $10 \mathrm{~m}$. They are formed during Late Weichselian (LW) stage of the last glaciation (Ostashkovsky horizon) from $16 \mathrm{ka}$ BP to $13 \mathrm{ka}$ BP (Subetto et al., 1998). In the middle part of the basin fluvioglacial type of ridges is commoned. These are eskers and end-moraine ridges. They are filled with subhorizontal sands. These forms mark Neva stage of the LW Ice Sheet about 1413 ka BP (Saarnisto, 2001). The biggest part area of southern and middle parts of the lake is occupied with glacial lacustrine plains and slopes. They covered by varved clays of Baltic Glacial Lake (BGL), which were forming in period 13-11 ka BP (Subetto, 2009). Plains widespread on depths $0-60 \mathrm{~m}$ and are featured with the lowest amplitude and the largest square. Particularly, hilly-depressioned glacial lacustrine plain stands out on depths 50-60 m, where eskers and end-moraine ridges are mostly common. This is the area of the Neva stage glacial activity. The last accumulative type is lacustrine. It forms plains of basin's northern part. The main features are big thickness of Holocene sediments (10-20 m) and low amplitude.

\section{Discussion and conclusions}

Corresponding to geomorphological analysis there are four main factors that impacted on Ladoga lake's basin development in Late Glacial - Holocene period. The most significant is neotectonical activity which continues in present time. Signs of these movements can be observed all over the bottom. In area between the Valaamo archipelago and northern coasts they are most intensive. The velocity of Holocene movements in that part exceeds $3.1 \mathrm{~mm} /$ year. Moving to the south their intensity decreases significantly. In addition, some traces of paleoseismic Late-Pleistocene event are also fixed. Factor of glacial activity had been taking a place before $c a .13 \mathrm{ka}$ BP. It left glacial and fluvioglacial ridges, hills and heights which formed at the Neva stage ca. 14-13 ka BP. In period 13-11 ka BP there was BGL which accumulated specific varved clays. Accumulation rates of these sediments changed from $5 \mathrm{~mm}$ /year (most part of the bottom) to $20 \mathrm{~mm} /$ year (deep hollows and valleys). The last factor is Holocene lacustrine processes. These processes generate geomorphological inversion: in southern and middle parts with accumulative glacial lacustrine plains we can observe modern denudation, while in the northern part in areas of denudative structural geomorphological type modern accumulation happens. Velocity rates of Holocene accumulation were about 1.7-1.8 mm/year.

Our recent results are important to Lake Ladoga history investigation and for the planning of monitoring of lake ecosystem. The authors are grateful to M.Yu. Tokarev (Moscow State University) for providing materials on seismoacoustic profiling of Lake Ladoga. This work was prepared with the support of the RFBR grant 18-05-00303.

\section{References}

Amantov A.V. 2014. Geology of pre-Quaternary formations and tectonics of lake Ladoga. Regionalnaya geologiya $i$ metallogeniya 58: 22-32. (in Russian)

Amantov A.V., Spiridonov M.A. 1989. Geology of lake Ladoga. Sovetskaya geologiya 4: 83-89. (in Russian)

Anokhin V.M., Naumenko M.A., Nesterov N.A. 2016. Relief of the bottom of lake Ladoga and its relationship with disjunctives. Izvestiya RGO 148(2): 44-52. (in Russian)

Naumenko M.A. 2013. Analysis of Morphometric Characteristics of Bottom Relief of Lake Ladoga on the Basis of the Digital Model. Izvestiya RAN. Seria Geographicheskaya 1: 62-72. (in Russian)

Naumenko M.A. 2020. Lake Ladoga digital bathymetric models: development approaches and insight for limnological investigations. Limnological Review 20(2): 65-80. DOI: 10.2478/ limre-2020-0008

Saarnisto M., Saarinen T. 2001. Deglaciation chronology of the Scandinavian Ice Sheet from the Lake Onega Basin to the Salpausselkä End Moraines. Global and Planetary Change 31(1): 387-405. DOI: 10.1016/S0921-8181(01)00131-X

Semenovich N.I. 1966. Bottom sediments of lake Ladoga. Leningrad: Nauka. (in Russian)

Subetto D.A, Davydova N.N., Rybalko A.E. 1998. Contribution to the lithostratigraphy and history of Lake Ladoga. Paleogeography, Paleoclimatology, Paleoecology 140(1): 113-119. DOI: 10.1016/S0031-0182(98)00032-7

Subetto D.A. 2009. Bottom sediments of lakes: paleogeographic reconstructions. Saint-Petersburg: est. of Herzen State Pedagogical University of Russia. (in Russian) 